\title{
Synthesis of carbon-11-labeled CK1 inhibitors as new potential PET radiotracers for imaging of Alzheimer's disease
}

\author{
Mingzhang Gao, Min Wang, Qi-Huang Zheng* \\ Department of Radiology and Imaging Sciences, Indiana University School of Medicine, 1345 West $16^{\text {th }}$ Street, Room 202, \\ Indianapolis, IN 46202, USA \\ *Corresponding author. Tel.: +1 317-278-4671. Fax: +1 317-278-9711. E-mail address: qzheng@iupui.edu.
}

This is where the receipt/accepted dates will go; Received Month XX, 2018; Accepted Month XX, 2018 [BMCL RECEIPT]

\begin{abstract}
The reference standards methyl 3-((2,2-difluoro-5H-[1,3]dioxolo[4',5':4,5]benzo[1,2-d]imidazol-6-yl)carbamoyl)benzoate (5a) and $N$-(2,2-difluoro-5H-[1,3]dioxolo[4',5':4,5]benzo[1,2-d]imidazol-6-yl)-3-methoxybenzamide (5c), and their corresponding desmethylated precursors 3-((2,2-difluoro-5H-[1,3]dioxolo[4',5':4,5]benzo[1,2-d]imidazol-6-yl)carbamoyl)benzoic acid (6a) and $N$-(2,2difluoro-5H-[1,3]dioxolo[4',5':4,5]benzo[1,2- $d$ ]imidazol-6-yl)-3-hydroxybenzamide (6b), were synthesized from 5-amino-2,2-difluoro1,3-benzodioxole and 3-substituted benzoic acids in 5 and 6 steps with $33 \%$ and $11 \%, 30 \%$ and $7 \%$ overall chemical yield, respectively. Carbon-11-labeled casein kinase 1 (CK1) inhibitors, [ $\left.{ }^{11} \mathrm{C}\right]$ methyl 3-((2,2-difluoro-5H-[1,3]dioxolo[4',5':4,5]benzo[1,2- $d$ ] imidazol-6yl)carbamoyl)benzoate $\left(\left[{ }^{11} \mathrm{C}\right] \mathbf{5 a}\right)$ and $N$-(2,2-difluoro-5H-[1,3]dioxolo[4',5':4,5]benzo[1,2- $\left.d\right]$ imidazol-6-yl)-3-[ $\left.{ }^{11} \mathrm{C}\right]$ methoxybenzamide $\left(\left[{ }^{11} \mathrm{C}\right] \mathbf{5} \mathbf{c}\right)$, were prepared from their $O$-desmethylated precursor $6 \mathbf{a}$ or $\mathbf{6 b}$ with $\left[{ }^{11} \mathrm{C}_{\mathrm{CH}_{3} \mathrm{OTf}}\right.$ through $O$ - $\left[{ }^{11} \mathrm{C}\right]$ methylation and isolated by HPLC combined with SPE in 40-45\% radiochemical yield, based on $\left[{ }^{11} \mathrm{C}_{C} \mathrm{CO}_{2}\right.$ and decay corrected to end of bombardment (EOB). The radiochemical purity was $>99 \%$, and the molar activity (MA) at EOB was $370-740 \mathrm{GBq} / \mu \mathrm{mol}$ with a total synthesis time of $\sim 40-\mathrm{minutes}$ from EOB.
\end{abstract}

Keywords: Casein kinase 1 (CK1); Carbon-11-labeled CK1 inhibitors; Radiosynthesis; Positron emission tomography (PET); Alzheimer's disease (AD).

Casein kinases (CK) are serine/threonine-specific enzymes and can be divided two subtypes: casein kinase 1 (CK1) and casein kinase 2 (CK2). ${ }^{1}$ CK1 contains at least seven isoforms $(\alpha, \beta, \gamma 1, \gamma 2, \gamma 3, \delta$ and $\varepsilon)$ expressed in eukaryotic organisms, CK1 is involved in various cellular processes including membrane trafficking, circadian rhythm, cell cycle progression, chromosome segregation, apoptosis and cellular differentiation, and deregulation of CK1 activity is linked to several pathological disorders and diseases like cancer, neurodegenerative diseases such as Alzheimer's disease (AD), Parkinson's disease (PD) and amyotrophic lateral sclerosis (ALS), and inflammatory disorders. ${ }^{2,3}$ The overexpression of CK1 has been described in the human AD brain, since CK1 leads to an increase in amyloid- $\beta$ $(\mathrm{A} \beta)$ peptide production, and also participates in the tau fibrillization reaction pathway through phosphorylation of tau. ${ }^{4,5}$ CK1 has become an interesting therapeutic target for $\mathrm{AD}$ where an urgent need for effective treatment exists, because it opens the door for the use of CK1 inhibitors as novel therapeutic approaches for AD. ${ }^{6} \mathrm{CK} 1$ inhibitors can prevent $\mathrm{A} \beta$ formation and reverse tau hyperphosphorylation in $\mathrm{AD}$, and have been used to treat neurodegenerative disorders including AD. ${ }^{4,5,7}$ Recently a new series of difluoro-dioxolobenzoimidazol-benzamides have been developed as potent CK1 inhibitors with nanomolar inhibitory activity, these compounds exhibited significant inhibitory effects on several tumor cell lines, and their in vitro biological data suggested they can be as therapeutics for $\mathrm{AD}$ as well. ${ }^{8}$

$\mathrm{AD}$ is a complicated neurodegenerative disease in the central nervous system (CNS), the cause of AD remains unclear, and so far no any effective treatment strategy is approved for preventing, curing and slowing the progress of AD. ${ }^{9}$ To discover more effective treatments, more accurate diagnostic tools are crucial to reveal new 
therapeutic targets. ${ }^{10}$ New noninvasive diagnostic imaging modalities for AD are really needed, both to detect and monitor the evolution of this disease, and to evaluate the efficacy of treatments. ${ }^{11}$ Advanced biomedical imaging technique positron emission tomography (PET) is one of the most widespread imaging techniques for $\mathrm{AD}$, and significant progress has been made to develop PET agents for two key neuropathological substrates of $\mathrm{AD}: \mathrm{A} \beta$ plaques and tau neurofibrillary tangles (NFTs). ${ }^{12,13}$ The representative PET $A \beta$ and tau tracers $\left[{ }^{11} \mathrm{C}\right] \mathrm{PIB}$ and $\left[{ }^{18} \mathrm{~F}\right]$ Amyvid $\left(\left[{ }^{18} \mathrm{~F}\right] \mathrm{AV}-45\right) ;{ }^{14,15}\left[{ }^{11} \mathrm{C}\right] \mathrm{PBB} 3$ and $\left[{ }^{18} \mathrm{~F}\right] \mathrm{T} 807\left(\left[{ }^{18} \mathrm{~F}\right] \mathrm{AV}-\right.$ $1451)^{16,17}$ are listed in Figure 1. The development of PET imaging probes for in vivo detection of Alzheimer's brains is critical for early and accurate diagnosis and for the successful discovery of $\mathrm{AD}$ therapies. ${ }^{18}$ The success and limitations of $\mathrm{A} \beta$ imaging and tau imaging have spurred efforts worldwide to develop new selective PET tracers for different imaging targets. CK1 has emerged as a new molecular imaging target of $\mathrm{AD},{ }^{19}$ but so far no any carbon-11 or fluorine18 labeled CK1 inhibitors as PET radiotracers for imaging of CK1 were reported. We are interested in the development of new PET AD imaging agents, and a series of enzyme- or receptor-based PET agents have been developed in this laboratory. In our previous work, we have targeted the enzyme glycogen synthase kinase3 (GSK-3) and developed carbon-11-labeled GSK-3 inhibitors; ${ }^{20,21}$ and we have also targeted serotonin (5hydroxytryptamine) 6 receptor $\left(5-\mathrm{HT}_{6} \mathrm{R}\right)$ and developed carbon-11-labeled 5 - $\mathrm{HT}_{6} \mathrm{R}$ antagonists, ${ }^{22}$ as PET radiotracers for $\mathrm{AD}$ imaging (Figure 1). In this ongoing study, we first target CK1, which is a novel and attractive molecular target for treatment and PET imaging of $\mathrm{AD} .{ }^{19}$ Here, we report the design, synthesis and labeling of carbon-11-labeled CK1 inhibitors, $\left.{ }^{11} \mathrm{C}\right]$ methyl 3-((2,2-difluoro-5H[1,3]dioxolo[4',5':4,5]benzo[1,2-d]imidazol-6-

yl)carbamoyl)benzoate $\left(\left[^{11} \mathrm{C}\right] 5 \mathbf{5 a}\right)$ and $N$-(2,2-difluoro$5 H$-[1,3]dioxolo[4',5':4,5]benzo[1,2- $d$ ]imidazol-6-yl)-3$\left[{ }^{11} \mathrm{C}\right]$ methoxybenzamide $\left(\left[{ }^{11} \mathrm{C}\right] \mathbf{5 c}\right)$, as new potential PET radiotracers for imaging of $\mathrm{AD}$, for the first time. The basic evaluations of the radiotracers including lipophilicity and stability are presented as well.

The reference standards methyl 3-((2,2-difluoro-5 $\mathrm{H}$ [1,3]dioxolo[4',5':4,5]benzo[1,2- $d$ ] imidazol-6-

yl)carbamoyl)benzoate (5a) and $\mathrm{N}$-(2,2-difluoro-5 $\mathrm{H}$ [1,3]dioxolo[4',5':4,5]benzo[1,2- $d$ ] imidazol-6-yl)-3-

methoxybenzamide $(\mathbf{5 c})$, and their corresponding desmethylated precursors 3-((2,2-difluoro-5 H[1,3]dioxolo[4',5':4,5]benzo[1,2- $d$ ] imidazol-6-

yl)carbamoyl)benzoic acid (6a) and $\mathrm{N}$-(2,2-difluoro-5H[1,3]dioxolo[4',5':4,5]benzo[1,2- $d$ ]imidazol-6-yl)-3hydroxybenzamide (6b), were synthesized as shown in Scheme 1 , according to the literature method $^{8}$ with modifications. The commercially available starting material 5-amino-2,2-difluoro-1,3-benzodioxole was treated with acetic anhydride in toluene to obtain acetamide $\mathbf{1}$ in $92 \%$ yield. Compound $\mathbf{1}$ was then converted to the intermediate $\mathbf{2}$ through a concurrent nitration and deprotection with nitronium tetrafluoroborate $\left(\mathrm{NO}_{2} \mathrm{BF}_{4}\right)$ in $69 \%$ yield. In comparison with the reported method, ${ }^{8}$ the use of the nitration reagent $\mathrm{NO}_{2} \mathrm{BF}_{4}$ simplified the reaction steps, combining nitration reaction and deprotecting reaction into one step, and improved the reaction yield. The nitro compound $\mathbf{2}$ was reduced through hydrogenation using $\mathrm{H}_{2}$ and $\mathrm{Pd} / \mathrm{C}$ as catalyst instead of Raney Nickel reported in the literature ${ }^{8}$ to give the intermediate $\mathbf{3}$ containing two amino groups, which was subsequently reacted with cyanogen bromide to provide the key intermediate amino 4 in $82 \%$ yield. The catalyst change in hydrogenation also improved the yield. Then the amino 4 was reacted with several 3 -substituted benzoic acids under the catalysis of $N, N, N^{\prime}, N^{\prime}$-tetramethyl- $O$ (1H-benzotriazol-1-yl)uronium hexafluorophosphate (HBTU) and $N, N$-diisopropylethylamine (DIPEA) to afford the standard compounds $\mathbf{5 a}$ and $\mathbf{5 c}$ in $63 \%$ and $21 \%$ yield, respectively. A protected benzamide $\mathbf{5 b}$ was also synthesized in $18 \%$ yield. Compound $\mathbf{5 a}$ was hydrolyzed in methanol solution of $\mathrm{KOH}$ to yield its acid precursor $\mathbf{6 a}$ in $93 \%$ yield. Compound $\mathbf{5 b}$ was converted to $O$-desmethylated precursor $\mathbf{6 b}$ for compound 5c through the deprotecting reaction of benzyl group employing boron trifluoride diethyl etherate $\left(\mathrm{BF}_{3} \cdot \mathrm{Et}_{2} \mathrm{O}\right)$ and dimethyl sulfide $\left(\mathrm{Me}_{2} \mathrm{~S}\right)$ in $65 \%$ yield. This deprotective reagent system was found to be better than other deprotective reagent system like $\mathrm{H}_{2}$ and $\mathrm{Pd} / \mathrm{C}$, which is easy to result in byproduct formation and lower yield.

Synthesis of the target tracers $\left[{ }^{11} \mathrm{C}\right] \mathbf{5 a}$ and $\left[{ }^{11} \mathrm{C}\right] \mathbf{5 c}$ is indicated in Scheme 2. $O$-Desmethylated precursor 6a or $\mathbf{6 b}$ underwent $O-\left[{ }^{11} \mathrm{C}\right]$ methylation ${ }^{23,24}$ using the reactive $\left[{ }^{11} \mathrm{C}\right]$ methylating agent $\left[{ }^{11} \mathrm{C}\right]$ methyl triflate $\left(\left[{ }^{11} \mathrm{C}\right] \mathrm{CH}_{3} \mathrm{OTf}\right)^{25,26}$ in acetonitrile at $80{ }^{\circ} \mathrm{C}$ under basic conditions $(2 \mathrm{~N} \mathrm{NaOH})$. The product was isolated by semi-preparative reverse-phase (RP) high performance liquid chromatography (HPLC) with a C-18 column, and then concentrated by solid-phase extraction $(\mathrm{SPE})^{27,28}$ with a disposable C-18 Light Sep-Pak cartridge to produce the corresponding pure radiolabeled compound $\left[{ }^{11} \mathrm{C}\right] \mathbf{5 a}$ or $\left[{ }^{11} \mathrm{C}\right] \mathbf{5} \mathbf{c}$ in $40-45 \%$ radiochemical yield, decay corrected to end of bombardment $(\mathrm{EOB})$, based on $\left[{ }^{11} \mathrm{C}\right] \mathrm{CO}_{2}$.

The radiosynthesis was performed in a home-built automated multi-purpose $\quad\left[{ }^{11} \mathrm{C}\right]$-radiosynthesis module. $^{29-31}$ Our radiosynthesis module facilitated the overall design of the reaction, purification and reformulation capabilities in a fashion suitable for 
adaptation to preparation of human doses. The radiosynthesis includes three stages: 1) labeling reaction; 2) purification; and 3) formulation. More reactive $\left[{ }^{11} \mathrm{C}^{-} \mathrm{CH}_{3} \mathrm{OTf}\right.$, instead of commonly used $\left[{ }^{11} \mathrm{C}\right]$ methyl iodide $\left(\left[{ }^{11} \mathrm{C}\right] \mathrm{CH}_{3} \mathrm{I}\right),{ }^{32}$ was used in $O$ $\left[{ }^{11} \mathrm{C}\right]$ methylation to improve radiochemical yield of $\left[{ }^{11} \mathrm{C}\right] 5 \mathbf{a}$ and $\left[{ }^{11} \mathrm{C}\right] \mathbf{5 c}$. The Eckert \& Ziegler Modular Lab C-11 Methyl Iodide/Triflate module in our facility can produce $\left[{ }^{11} \mathrm{C}\right]$ methylating agent either $\left[{ }^{11} \mathrm{C}^{1} \mathrm{CH}_{3} \mathrm{OTf}\right.$ or $\left[{ }^{11} \mathrm{C}\right] \mathrm{CH}_{3} \mathrm{I}\left(\left[{ }^{11} \mathrm{C} \mathrm{CH}_{3} \mathrm{Br}\right.\right.$ passed through a $\mathrm{NaI}$ column). The direct comparison between $\left[{ }^{11} \mathrm{C}^{2} \mathrm{CH}_{3} \mathrm{OTf}\right.$ and $\left[{ }^{11} \mathrm{C}_{\mathrm{CH}_{3} \mathrm{I}}\right.$ confirmed the result that the labeling yield was improved from $30-35 \%$ to $40-45 \%$. The labeling reaction was conducted using a $\mathrm{V}$-vial method. Addition of aqueous $\mathrm{NaHCO}_{3}$ to quench the radiolabeling reaction and to dilute the radiolabeling mixture prior to the injection onto the semi-preparative HPLC column for purification gave better separation of $\left[{ }^{11} \mathrm{C}\right] \mathbf{5 a}$ or $\left[{ }^{11} \mathrm{C}\right] \mathbf{5} \mathbf{c}$ from its $O$-desmethylated precursor $\mathbf{6 a}$ or $\mathbf{6 b}$. Both Sep-Pak trap/release and rotatory evaporation are available for formulation in our multi-purpose $\left[{ }^{11} \mathrm{C}\right]$ radiosynthesis module, and we used Sep-Pak method instead of rotatory evaporation for formulation to improve the chemical purity of radiolabeled product $\left[{ }^{11} \mathrm{C}\right] \mathbf{5 a}$ or $\left[{ }^{11} \mathrm{C}\right] \mathbf{5 c}$. The direct comparison between SepPak method and rotatory evaporation confirmed the result that the chemical purity of radiolabeled product was improved from $<90 \%$ to $>90 \%$. In addition, a C18 Light Sep-Pak to replace a C18 Plus Sep-Pak allowed final product formulation with $\leq 5 \%$ ethanol. ${ }^{33}$ Overall, it took $\sim 40 \mathrm{~min}$ for synthesis, purification and dose formulation.

Our module is designed to allow in-process measurement of $\left[{ }^{11} \mathrm{C}\right]$-tracer molar activity (MA, $\mathrm{GBq} / \mu \mathrm{mol}$ at $\mathrm{EOB}$ ) using a radiation detector with a UV detector at the outlet of the HPLC-portion of the system. ${ }^{31}$ In the HPLC chromatogram, peak analysis of the chromatographic data utilized PeakSimple software (SRI Instruments, Las Vegas, NV). Immediately following elution of the product peak, the chromatographic data are exported to PeakSimple readable files, and the area of the radioactivity peak is converted to $\mathrm{GBq}-\mathrm{mCi}$ at $\mathrm{EOB}$ by comparison to a reference calibration curve previously constructed using the same detector, loop column, mobile phase and flow rate. The mass peak from the UV chromatogram (without decay correction) is similarly compared to a standard curve made at the same UV wavelength, mobile phase and flow rate. Simple division of the total EOB radioactivity peak (in $\mathrm{GBq}-\mathrm{mCi}$ ) by the total mass peak (in nmoles) gives specific activity at EOB in $\mathrm{GBq}-\mathrm{Ci} / \mu \mathrm{mol}$. For the reported syntheses, product MA was in a range of $370-740 \mathrm{GBq} / \mu \mathrm{mol}$ at EOB. The factors that affect the EOB MA significantly to lead to such a wide range have been discussed in our previous works. $^{34-36}$ The general methods to increase SA have been described as well, and the SA of our $\left[{ }^{11} \mathrm{C}\right]$-tracers is significantly improved. ${ }^{34-36}$ The 'wide range' of MA we reported is for the same $\left[{ }^{11} \mathrm{C}\right]$-tracer produced in different days, because very different $\left[{ }^{11} \mathrm{C}\right]$-target and $\left[{ }^{11} \mathrm{C}\right]$-radiosynthesis unit situations would make MA in a wide range. For a $\left[{ }^{11} \mathrm{C}\right]$-tracer produced in the same day, the MA of the same tracer in different production runs will be in a small range, because $\left[{ }^{11} \mathrm{C}\right]$-target and $\left[{ }^{11} \mathrm{C}\right]$-radiosynthesis unit would not be much different in the same day. Likewise, the methods to minimize such wide range of MA from practice perspective have been provided in our previous works. ${ }^{34-36}$ At the end of synthesis (EOS), the MA of $\left[{ }^{11} \mathrm{C}\right]$-tracer was determined again by analytical RP HPLC, calculated, decay corrected to EOB, and based on $\left[{ }^{11} \mathrm{C}\right] \mathrm{CO}_{2}$, which was in agreement with the 'on line' determined value. In this work, semi-preparative HPLC was used for purification, thus the MA of $\left[{ }^{11} \mathrm{C}\right]$-tracer was assessed by both semipreparative HPLC (during synthesis) and analytical HPLC (EOS).

Chemical purity and radiochemical purity were determined by analytical HPLC. ${ }^{37}$ The chemical purity of the precursor and reference standard was $>93 \%$. The radiochemical purity of the target tracer was $>99 \%$ determined by radio-HPLC through $\gamma$-ray (PIN diode) flow detector, and the chemical purity of the target tracer was $>90 \%$ determined by reversed-phase HPLC through UV flow detector.
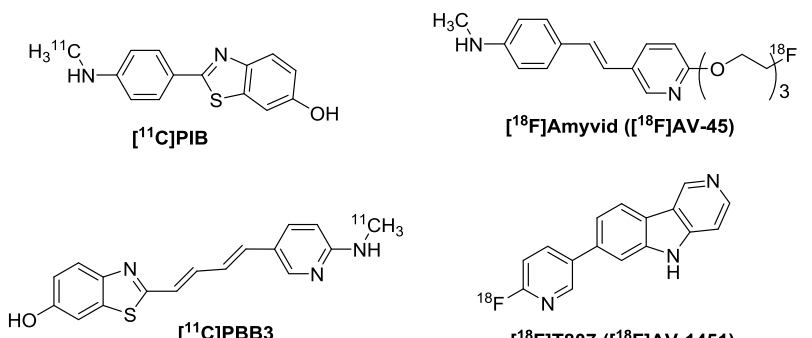

$\left[{ }^{18} \mathrm{~F}\right] \mathrm{T} 807\left(\left[{ }^{18} \mathrm{~F}\right] \mathrm{AV}-1451\right)$
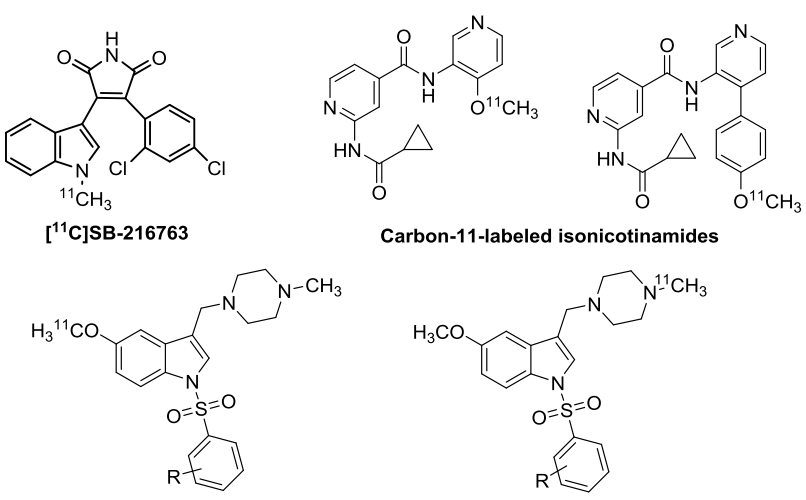

Carbon-11-labeled isonicotinamides

Carbon-11-labeled 5- $\mathrm{HT}_{6} \mathrm{R}$ antagonists $(\mathrm{R}=2-\mathrm{Br} ; \mathrm{H} ; 4$-i $\mathrm{Pr} ; 4-\mathrm{F})$

Figure 1. PET radiotracers for imaging of AD. 


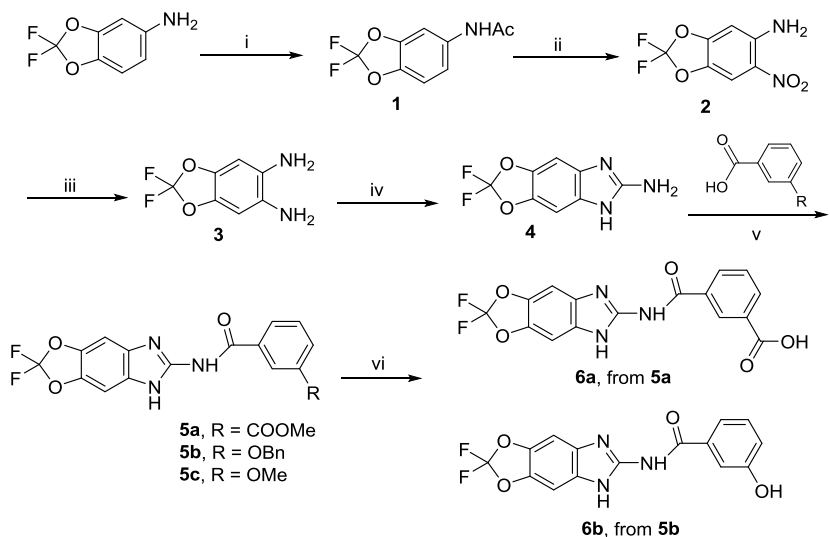

Scheme 1. Synthesis of reference standards $\mathbf{5 a} ; \mathbf{5 c}$ and $O$-desmethylated precursors $\mathbf{6 a} ; \mathbf{6 b}$. Reaction reagents, conditions and yields: (i) acetic anhydride, toluene, $100{ }^{\circ} \mathrm{C}$, 92\%. (ii) $\mathrm{NO}_{2} \mathrm{BF}_{4}, \mathrm{CH}_{2} \mathrm{Cl}_{2}, 69 \%$. (iii) hydrogen, $\mathrm{Pd} / \mathrm{C}$, methanol; (iv) cyanogen bromide, methanol, room temperature (RT), 40 h, 82\%. (v) 3-substitutent-benzoic acid, HBTU, DIPEA, 18-63\%. (vi) for $\mathbf{6 a}, \mathrm{KOH}$, methanol, 93\%; for $\mathbf{6 b}, \mathrm{Me}_{2} \mathrm{~S}$, $\mathrm{BF}_{3} \cdot \mathrm{Et}_{2} \mathrm{O}, \mathrm{CH}_{2} \mathrm{Cl}_{2}, 65 \%$.

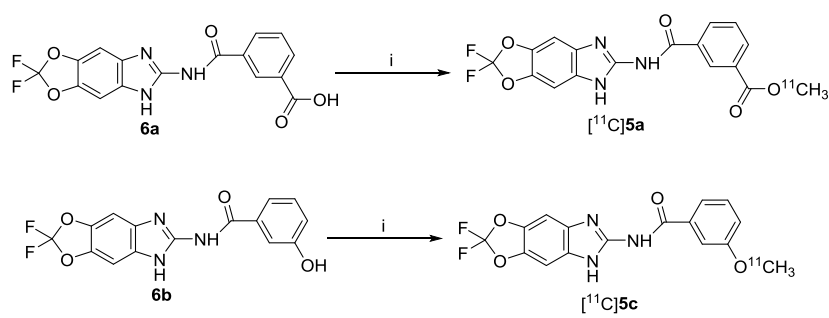

Scheme 2. Synthesis of target tracers $\left[{ }^{11} \mathrm{C}\right] \mathbf{5 a}$ and $\left[{ }^{11} \mathrm{C}\right] \mathbf{5} \mathbf{c}$. Reaction reagents, conditions and yields: (i) $\left[{ }^{11} \mathrm{C}_{\mathrm{CH}_{3}} \mathrm{OTf}, \mathrm{CH}_{3} \mathrm{CN}, 2 \mathrm{~N} \mathrm{NaOH}, 80\right.$ ${ }^{\circ} \mathrm{C}, 3$ min; HPLC-SPE, 40-45\%.

Table 1. $\log P$ and CLog P values of carbon-11-labeled $\mathrm{CK} 1$ inhibitors $\left[{ }^{11} \mathrm{C}\right] \mathbf{5 a}$ and $\left[{ }^{11} \mathrm{C}\right] \mathbf{5 c}$ in comparison with $\left[{ }^{11} \mathrm{C}\right] \mathrm{PIB},\left[{ }^{18} \mathrm{~F}\right]$ Amyvid, $\left[{ }^{11} \mathrm{C}\right] \mathrm{PBB} 3$ and $\left[{ }^{18} \mathrm{~F}\right] \mathrm{T} 807$.

\begin{tabular}{|c|c|c|}
\hline Compound & Log P & CLog P \\
\hline$\left[{ }^{11} \mathbf{C}\right] \mathbf{5 a}$ & 3.60 & 5.09 \\
\hline$\left[{ }^{11} \mathbf{C}\right] \mathbf{5}$ & 3.66 & 5.12 \\
\hline$\left[{ }^{11} \mathbf{C}\right] \mathbf{P I B}$ & 3.41 & 3.99 \\
\hline$\left[{ }^{18} \mathbf{F}\right]$ Amyvid & 3.16 & 3.91 \\
\hline$\left[{ }^{11} \mathbf{C}\right] \mathbf{P B B 3}$ & 4.09 & 4.05 \\
\hline$\left[{ }^{18} \mathbf{F}\right] \mathbf{T 8 0 7}$ & 2.25 & 3.18 \\
\hline
\end{tabular}

The octanol-water partition coefficient (commonly expressed as $\log \mathrm{P}$ ) is an important physical parameter directly correlated with the biological activities of a wide variety of organic compounds. ${ }^{36,38}$ Log P provides an assessment of lipophilicity that often correlates with a compound's ability to penetrate the blood brain barrier (BBB). Log P can be determined experimentally by liquid-liquid extraction and by HPLC ${ }^{38}$ and can also be theoretically calculated from parameters related to the structure of molecules. We obtained $\log \mathrm{P}$ and calculated $\log \mathrm{P}(\mathrm{C} \log \mathrm{P})$ values of carbon-11-labeled CK1 inhibitors $\left[{ }^{11} \mathrm{C}\right] \mathbf{5 a}$ and $\left[{ }^{11} \mathrm{C}\right] \mathbf{5 c}$ in comparison with $\left[{ }^{11} \mathrm{C}\right] \mathrm{PIB}, \quad\left[{ }^{18} \mathrm{~F}\right]$ Amyvid, $\left[{ }^{11} \mathrm{C}\right] \mathrm{PBB} 3$ and $\left[{ }^{18} \mathrm{~F}\right] \mathrm{T} 807$ (Figure 1) from ChemDraw Professional 15.1
(ChemOffice), and the data are listed in Table 1. Log P data of $\left[{ }^{11} \mathrm{C}\right] \mathbf{5 a}$ and $\left[{ }^{11} \mathrm{C}\right] \mathbf{5 c}(3.60-3.66)$ are in the range of Log P data of $\left[{ }^{11} \mathrm{C}\right] \mathrm{PIB},\left[{ }^{18} \mathrm{~F}\right]$ Amyvid, $\left[{ }^{11} \mathrm{C}\right] \mathrm{PBB} 3$ and $\left[{ }^{18} \mathrm{~F}\right] \mathrm{T} 807(2.25-4.09)$, which are PET AD imaging agents in clinical evaluation. These data suggest $\left[{ }^{11} \mathrm{C}\right] \mathbf{5 a}$ and $\left[{ }^{11} \mathrm{C}\right] \mathbf{5} \mathbf{c}$ have appropriate lipophilicity to pass the BBB for brain uptake.

The stability of the labeled tracers $\left[{ }^{11} \mathrm{C}\right] \mathbf{5 a}$ and $\left[{ }^{11} \mathrm{C}\right] \mathbf{5 c}$ was evaluated by analytical HPLC from EOS up to $3 \mathrm{~h}$, one injection of the tracer solution in $\mathrm{EtOH} /$ saline onto HPLC column per hour. The HPLC chromatograms showed $\left[{ }^{11} \mathrm{C}\right] \mathbf{5 a}$ and $\left[{ }^{11} \mathrm{C}\right] \mathbf{5 c}$ were stable without decomposition.

The experimental details and characterization data for compounds 1-6 and for the tracers $\left[{ }^{11} \mathrm{C}\right] \mathbf{5 a}$ and $\left[{ }^{11} \mathrm{C}\right] \mathbf{5 c}$ are given. ${ }^{39}$

In summary, synthetic routes with moderate to high yields have been developed to produce difluorodioxolo-benzoimidazol-benzamides including reference standards $5 \mathbf{a}$ and $\mathbf{5 c}$, and $O$-desmethylated precursors $\mathbf{6 a}$ and $\mathbf{6 b}$, and carbon-11-labeled difluoro-dioxolobenzoimidazol-benzamides target tracers $\left[{ }^{11} \mathrm{C}\right] \mathbf{5 a}$ and $\left[{ }^{11} \mathrm{C}\right] 5 \mathbf{c}$. The radiosynthesis employed $\left[{ }^{11} \mathrm{C}\right] \mathrm{CH}_{3} \mathrm{OTf}$ for $O-\left[{ }^{11} \mathrm{C}\right]$ methylation at $O$-desmethylated precursor, followed by product purification and isolation using a semi-preparative RP HPLC combined with SPE. $\left[{ }^{11} \mathrm{C}\right] \mathbf{5 a}$ and $\left[{ }^{11} \mathrm{C}\right] \mathbf{5} \mathbf{c}$ were obtained in high radiochemical yield, radiochemical purity and chemical purity, with a reasonable short overall synthesis time, and high molar activity. This will facilitate studies to evaluate carbon-11-labeled CK1 inhibitors $\left[{ }^{11} \mathrm{C}\right] \mathbf{5 a}$ and $\left[{ }^{11} \mathrm{C}\right] \mathbf{5 c}$ as new candidate PET radiotracers for imaging of $\mathrm{AD}$.

\section{Acknowledgments}

This work was partially supported by Indiana University Department of Radiology and Imaging Sciences in the United States. ${ }^{1} \mathrm{H}$ NMR and ${ }^{13} \mathrm{C}$ NMR spectra were recorded at 500 and $125 \mathrm{MHz}$, respectively, on a Bruker Avance II $500 \mathrm{MHz}$ NMR spectrometer in the Department of Chemistry and Chemical Biology at Indiana University Purdue University Indianapolis (IUPUI), which is supported by the United States National Science Foundation (NSF) Major Research Instrumentation Program (MRI) grant CHE-0619254.

\section{References and notes}

1. Schittek B, Sinnberg T. Biological functions of casein kinase 1 isoforms and putative roles in tumorigenesis. Mol Cancer. 2014;13:231. 
2. Vielhaber E, Virshup DM. Casein kinase I: from obscurity to center stage. IUBMB Life. 2001;51:7378.

3. Rudrabhatla P. Regulation of neuronal cytoskeletal protein phosphorylation in neurodegenerative diseases. J Alzheimer's Dis. 2014;41:671-684.

4. Flajolet M, He G, Heiman M, Lin A, Nairn AC, Greengard P. Regulation of Alzheimer's disease amyloid-beta formation by casein kinase I. Proc Natl Acad Sci U S A. 2007;104:4159-4164.

5. Li G, Yin H, Kuret J. Casein kinase 1 delta phosphorylates tau and disrupts its binding to microtubules. J Biol Chem. 2004;279:15938-15945.

6. Perez DI, Gil C, Martinez A. Protein kinases CK1 and CK2 as new targets for neurodegenerative diseases. Med Res Rev. 2011;31:924-954.

7. Benek O, Hroch L, Aitken L, Gunn-Moore F, Vinklarova L, Kuca K, Perez DI, Perez C, Martinez A, Fisar Z, Musilek K. 1-(Benzo[d]thiazol-2-yl)-3phenylureas as dual inhibitors of casein kinase 1 and ABAD enzymes for treatment of neurodegenerative disorders. J Enzyme Inhib Med Chem. 2018;33:665670.

8. Richter J, Bischof J, Zaja M, Kohlhof H, Othersen O, Vitt D, Alscher V, Pospiech I, García-Reyes B, Berg S, Leban J, Knippschild U. Difluoro-dioxolobenzoimidazol-benzamides as potent inhibitors of CK1 $\delta$ and $\varepsilon$ with nanomolar inhibitory activity on cancer cell proliferation. J Med Chem. 2014;57:79337946.

9. Wang M, Gao M, Zheng Q.-H. The first synthesis of $\left[{ }^{11} \mathrm{C}\right] \mathrm{J} 147$, a new potential PET agent for imaging of Alzheimer's disease. Bioorg Med Chem Lett. 2013;23:524-527.

10. Pietrzak K, Czarnecka K, Mikiciuk-Olasik E, Szymanski P. New perspectives of Alzheimer disease diagnosis - the most popular and future methods. Med Chem. 2018;14:34-43.

11. Mach RH. New targets for the development of PET tracers for imaging neurodegeneration in Alzheimer disease. J Nucl Med. 2014;55:1221-1224.

12. Hall B, Mak E, Cervenka S, Aigbirhio FI, Rowe JB, O'Brien JT. In vivo tau PET imaging in dementia: Pathophysiology, radiotracer quantification, and a systematic review of clinical findings. Ageing Res Rev. 2017;36:50-63.

13. Oukoloff K, Cieslikiewicz-Bouet M, Chao S, Da Costa Branquinho E, Bouteiller C, Jean L, Renard PY. PET and SPECT radiotracers for Alzheimer's disease. Curr Med Chem. 2015;22:3278-3304.

14. Klunk WE, Engler H, Nordberg A, Bacskai BJ, Wang Y, Price JC, Bergström M, Hyman BT, Långström B, Mathis CA. Imaging the pathology of Alzheimer's disease: amyloid-imaging with positron emission tomography. Neuroimaging Clin N Am. 2003;13:781789.

15. Carpenter AP Jr, Pontecorvo MJ, Hefti FF, Skovronsky DM. The use of the exploratory IND in the evaluation and development of ${ }^{18} \mathrm{~F}$-PET radiopharmaceuticals for amyloid imaging in the brain: a review of one company's experience. Q J Nucl Med Mol Imaging. 2009;53:387-393.

16. Hashimoto $\mathrm{H}$, Kawamura $\mathrm{K}$, Igarashi $\mathrm{N}$, Takei $\mathrm{M}$, Fujishiro T, Aihara Y, Shiomi S, Muto M, Ito T, Furutsuka K, Yamasaki T, Yui J, Xie L, Ono M, Hatori A, Nemoto K, Suhara T, Higuchi M, Zhang MR. Radiosynthesis, photoisomerization, biodistribution, and metabolite analysis of ${ }^{11} \mathrm{C}-\mathrm{PBB} 3$ as a clinically useful PET probe for imaging of tau pathology. J Nucl Med. 2014;55:1532-1538.

17. Chien DT, Bahri S, Szardenings AK, Walsh JC, Mu F, Su MY, Shankle WR, Elizarov A, Kolb HC. Early clinical PET imaging results with the novel PHF-tau radioligand [F-18]-T807. J Alzheimers Dis. 2013;34:457-468.

18. Okamura N, Harada R, Furukawa K, Furumoto S, Tago T, Yanai K, Arai H, Kudo Y. Advances in the development of tau PET radiotracers and their clinical applications. Ageing Res Rev. 2016;30:107-113.

19. Wager TT, Galatsis P, Chandrasekaran RY, Butler TW, Li J, Zhang L, Mente S, Subramanyam C, Liu S, Doran AC, Chang C, Fisher K, Grimwood S, Hedde JR, Marconi M, Schildknegt K. Identification and profiling of a selective and brain penetrant radioligand for in vivo target occupancy measurement of casein kinase 1 (CK1) inhibitors. ACS Chem Neurosci. 2017;8:1995-2004.

20. Wang M, Gao M, Miller KD, Sledge GW, Hutchins GD, Zheng Q.-H. The first synthesis of $\left[{ }^{11} \mathrm{C}\right] \mathrm{SB}-$ 216763, a new potential PET agent for imaging of glycogen synthase kinase-3 (GSK-3). Bioorg Med Chem Lett. 2011;21:245-249.

21. Gao M, Wang M, Zheng Q.-H. Synthesis of carbon11-labeled isonicotinamides as new potential PET agents for imaging of GSK-3 enzyme in Alzheimer's disease. Bioorg Med Chem Lett. 2017;27:740-743.

22. Wang X, Dong F, Miao C, Li W, Wang M, Gao M, Zheng Q.-H, Xu Z. Synthesis of carbon-11-labeled 5$\mathrm{HT}_{6} \mathrm{R}$ antagonists as new potential PET radioligands for imaging of Alzheimer's disease. Bioorg Med Chem Lett. 2018;28:1836-1841.

23. Wang M, Gao M, Xu Z, Zheng Q.-H. Synthesis of $\left[{ }^{11} \mathrm{C}\right] \mathrm{HG}-10-102-01$ as a new potential PET agent for imaging of LRRK2 enzyme in Parkinson's disease. Bioorg Med Chem Lett. 2017;27:1351-1355.

24. Gao M, Wang M, Meyer JA, Peters JS, Zarrinmayeh H, Territo PR, Hutchins GD, Zheng Q.-H. Synthesis and preliminary biological evaluation of $\left[{ }^{11} \mathrm{C}\right]$ methyl (2-amino-5-(benzylthio)thiazolo[4,5- $d]$ pyrimidin-7yl)-d-leucinate for the fractalkine receptor (CX3CR1). Bioorg Med Chem Lett. 2017;27:2727-2730.

25. Jewett DM. A simple synthesis of $\left[{ }^{11} \mathrm{C}\right]$ methyl triflate. Int J Rad Appl Instrum A. 1992;43:1383-1385.

26. Mock BH, Mulholland GK, Vavrek MT. Convenient gas phase bromination of $\left[{ }^{11} \mathrm{C}\right]$ methane and production of $\left[{ }^{11} \mathrm{C}\right]$ methyl triflate. Nucl Med Biol. 1999;26:467471. 
27. Wang M, Gao M, Miller KD, Zheng Q.-H. Synthesis of $\left[{ }^{11} \mathrm{C}\right]$ PBR06 and $\left[{ }^{8} \mathrm{~F}\right] \mathrm{PBR} 06$ as agents for positron emission tomographic (PET) imaging of the translocator protein (TSPO). Steroids. 2011;76:13311340.

28. Wang M, Gao M, Miller KD, Sledge GW, Zheng Q.H. $\left[{ }^{11} \mathrm{C}\right] \mathrm{GSK} 2126458$ and $\left[{ }^{18} \mathrm{~F}\right] \mathrm{GSK} 2126458$, the first radiosynthesis of new potential PET agents for imaging of PI3K and mTOR in cancers. Bioorg Med Chem Lett. 2012;22:1569-1574.

29. Wang M, Gao M, Zheng Q.-H. Fully automated synthesis of PET TSPO radioligands $\left[{ }^{11} \mathrm{C}\right] \mathrm{DAA} 1106$ and $\left[{ }^{18}\right.$ F]FEDAA1106. Appl Radiat Isot. 2012;70:965973.

30. Mock BH, Zheng Q.-H, DeGrado TR. A multipurpose ${ }^{11} \mathrm{C}$-radio-synthesis system. J Labelled Compd Radiopharm. 2005;48:S225.

31. Mock BH, Glick-Wilson BE, Zheng Q.-H, DeGrado TR. Automated measurement of specific activity of radiolabeled ligands during synthesis. J Labelled Compd Radiopharm. 2005;48:S224.

32. Allard M, Fouquet E, James D, Szlosek-Pinaud M. State of art in ${ }^{11} \mathrm{C}$ labelled radiotracers synthesis. Curr Med Chem. 2008;15:235-277.

33. Zheng Q.-H, Glick-Wilson BE, Steele B, Shaffer M, Corbin L, Green MA. A simplified conventional manual C18 Light Sep-Pak system for purification and reformulation of carbon-11 PET tracers. J Labelled Compd Radiopharm. 2015;58:S392.

34. Wang M, Gao M, Xu Z, Zheng Q.-H. Synthesis of a PET tau tracer $\left[{ }^{11} \mathrm{C}\right] \mathrm{PBB} 3$ for imaging of Alzheimer's disease. Bioorg Med Chem Lett. 2015;25:4587-4592.

35. Gao M, Wang M, Green MA, Hutchins GD, Zheng Q.-H. Synthesis of $\left[{ }^{11} \mathrm{C}\right] \mathrm{GSK} 1482160$ as a new PET agent for targeting $\mathrm{P}_{2} \mathrm{X}_{7}$ receptor. Bioorg Med Chem Lett. 2015;25:1965-1970.

36. Gao M, Wang M, Zheng Q.-H. Synthesis of $\left[{ }^{11} \mathrm{C}\right] \mathrm{MK}-$ 1064 as a new PET radioligand for imaging of orexin2 receptor. Bioorg Med Chem Lett. 2016;26:36943699.

37. Zheng Q.-H, Mock BH. Purification of carbon-11 PET radiotracers from unlabeled precursors by preparative HPLC and SPE. Biomed Chromatogr. 2005;19:671676.

38. Liu X, Wang JQ, Zheng Q.-H. Lipophilicity coefficients of potential tumor imaging agents, positron-labeled $\mathrm{O}^{6}$-benzylguanine derivatives. Biomed Chromatogr. 2005;19:379-384.

39. (a). General: All commercial reagents and solvents were purchased from Sigma-Aldrich and Fisher Scientific, and used without further purification. $\left[{ }^{11} \mathrm{C}\right] \mathrm{CH}_{3} \mathrm{OTf}$ was prepared according to a literature procedure. ${ }^{26}$ Melting points were determined on WRR apparatus and were uncorrected. ${ }^{1} \mathrm{H}$ and ${ }^{13} \mathrm{C}$ NMR spectra were recorded on a Bruker Avance II 500 MHz NMR Fourier transform spectrometer at 500 and $125 \mathrm{MHz}$, respectively. Chemical shifts $(\delta)$ are reported in parts per million (ppm) relative to an internal standard tetramethylsilane (TMS, $\delta 0.0)\left({ }^{1} \mathrm{H}\right.$
NMR) and to the solvent signal $\left({ }^{13} \mathrm{C} \mathrm{NMR}\right)$, and coupling constants $(J)$ are reported in hertz $(\mathrm{Hz})$. Liquid chromatography-mass spectra (LC-MS) analysis was performed on an Agilent system, consisting of an 1100 series HPLC connected to a diode array detector and a 1946D mass spectrometer configured for positive-ion/negative-ion electrospray ionization. The high resolution mass spectra (HRMS) were obtained using a Waters/Micromass LCT Classic spectrometer. Chromatographic solvent proportions are indicated as volume: volume ratio. Thin-layer chromatography (TLC) was run using Analtech silica gel GF uniplates $\left(5 \times 10 \mathrm{~cm}^{2}\right)$. Plates were visualized under UV light. Normal phase flash column chromatography was carried out on EM Science silica gel 60 (230-400 mesh) with a forced flow of the indicated solvent system in the proportions described below. All moisture- and air-sensitive reactions were performed under a positive pressure of nitrogen maintained by a direct line from a nitrogen source. Analytical RP HPLC was performed using a Prodigy (Phenomenex) $5 \mu \mathrm{m} \mathrm{C}-18$ column, $4.6 \times 250 \mathrm{~mm}$; mobile phase $60 \% \mathrm{CH}_{3} \mathrm{CN} / 40 \% \mathrm{H}_{2} \mathrm{O}$; flow rate 1.3 $\mathrm{mL} / \mathrm{min}$; UV (254 $\mathrm{nm}$ ) and $\gamma$-ray (PIN diode) flow detectors. Semi-preparative RP HPLC was performed using a Prodigy (Phenomenex) $5 \mu \mathrm{m} \mathrm{C}-18$ column, 10 $\times 250 \mathrm{~mm}$; mobile phase $60 \% \mathrm{CH}_{3} \mathrm{CN} / 40 \% \mathrm{H}_{2} \mathrm{O}$; flow rate $5 \mathrm{~mL} / \mathrm{min}$; UV $(254 \mathrm{~nm})$ and $\gamma$-ray (PIN diode) flow detectors. C18 Light Sep-Pak cartridges were obtained from Waters Corporation (Milford, MA). Sterile Millex-FG $0.2 \mu \mathrm{m}$ filter units were obtained from Millipore Corporation (Bedford, MA).

(b). $\quad N-(2,2-D i f l u o r o b e n z o[d][1,3]$ dioxol-5yl)acetamide (1): A solution of 5-amino-2,2-difluoro1,3-benzodioxole $(14.4 \mathrm{~g}, 83.2 \mathrm{mmol})$ in dry toluene $(230 \mathrm{~mL})$ and acetic anhydride $(9.76 \mathrm{~g}, 95.7 \mathrm{mmol}$, 1.15 equiv) was stirred at $100{ }^{\circ} \mathrm{C}$ for $3 \mathrm{~h}$. The solvent was removed under reduced pressure, then the crude product was dissolved in $80 \mathrm{~mL}$ of methanol to remove traces of acetic anhydride. The solvent was subsequently evaporated. The crude product was recrystallized from toluene, and the resulting product was filtered off and dried to give a beige crystal 1 (16.5 g, 92\%), $R_{f}=0.25$ (1:2 EtOAc/Hexanes), mp 140-142 ${ }^{\circ} \mathrm{C} .{ }^{1} \mathrm{H}$ NMR (DMSO-d 6 ): $\delta 2.05$ (s, 3H, $\mathrm{CH}_{3}$ ), 7.21 (dd, $\left.J=2.0,8.5 \mathrm{~Hz}, 1 \mathrm{H}, \mathrm{Ph}-\mathrm{H}\right), 7.31$ (d, $J$ $=8.5 \mathrm{~Hz}, 1 \mathrm{H}, \mathrm{Ph}-\mathrm{H}), 7.75(\mathrm{~d}, J=2.0 \mathrm{~Hz}, 1 \mathrm{H}, \mathrm{Ph}-\mathrm{H})$, 10.14 (s, 1H, NH). MS (ESI): $216\left([\mathrm{M}+\mathrm{H}]^{+}, 100 \%\right)$; MS (ESI): 214 ([M-H] $\left.]^{-}, 100 \%\right)$.

(c). 2,2-Difluoro-6-nitrobenzo[d][1,3]dioxol-5-amine (2): Compound 1 (15.6 g, $72.5 \mathrm{mmol}$ ) was dissolved in dichloromethane $(250 \mathrm{~mL})$. To the resulting mixture, nitronium tetrafluoroborate solution $(174 \mathrm{~mL}$, $0.5 \mathrm{M}$ in sulfolane) was added dropwise at $0{ }^{\circ} \mathrm{C}$. After addition, the reaction mixture was allowed to $\mathrm{RT}$ and stirred for $24 \mathrm{~h}$. Then the reaction mixture was evaporated to remove dichloromethane, and the resulting mixture was added with water, extracted 
with EtOAc, washed with water two times, and dried over $\mathrm{Na}_{2} \mathrm{SO}_{4}$. The mixture was filtered, and filtrate was evaporated in vacuo. The resultant residue was purified by column chromatography on silica gel with eluent (2:98 to 20:80 EtOAc/hexanes) to give a light beige solid 2 (10.9 g, 69\%), $R_{f}=0.73\left(\mathrm{CH}_{2} \mathrm{Cl}_{2}\right), \mathrm{mp}$ 138-140 ${ }^{\circ} \mathrm{C} .{ }^{1} \mathrm{H}$ NMR (DMSO-d 6 ): $\delta 6.94$ (s, $1 \mathrm{H}, \mathrm{Ph}-$ $\mathrm{H}), 7.79$ (s, 2H, $\mathrm{NH}_{2}$ ), 7.94 (s, 1H, Ph-H). MS (ESI): $219\left([\mathrm{M}+\mathrm{H}]^{+}, 3 \%\right) ; \mathrm{MS}(\mathrm{ESI}): 217\left([\mathrm{M}-\mathrm{H}]^{-}, 100 \%\right)$.

(d). 2,2-Difluorobenzo[d][1,3]dioxole-5,6-diamine (3): Compound $2(5.0 \mathrm{~g}, 22.9 \mathrm{mmol})$ was dissolved in methanol $(120 \mathrm{~mL})$ and hydrogenated under hydrogen atmosphere (55 psi) with $\mathrm{Pd} / \mathrm{C}(300-500 \mathrm{mg}$ ) as a catalyst for $4 \mathrm{~h}$. The reaction mixture was filtered over Celite 545 and washed with methanol. The solvent was evaporated in vacuo to obtain a purple solid $\mathbf{3}$, which was directly used for next step without further purification because this compound was unstable on silica gel column. $R_{f}=0.34\left(\mathrm{CH}_{2} \mathrm{Cl}_{2}\right)$. MS (ESI): 189 $\left([\mathrm{M}+\mathrm{H}]^{+}, 100 \%\right) ; \mathrm{MS}(\mathrm{ESI}): 187\left([\mathrm{M}-\mathrm{H}]^{-}, 45 \%\right)$.

(e). 2,2-Difluoro-5H-[1,3]dioxolo[4',5':4,5]benzo[1,2d]imidazol-6-amine (4): The crude product $3(0.94 \mathrm{~g}$, $5.0 \mathrm{mmol}$ ) was dissolved in dry methanol, cyanogen bromide $(795 \mathrm{mg}, 7.5 \mathrm{mmol}$ ) was added. The reaction mixture was stirred at RT for $40 \mathrm{~h}$. The reaction mixture was concentrated, and the residue was purified by column chromatography on silica gel with eluent (2:98 to $10: 90 \mathrm{MeOH} / \mathrm{CH}_{2} \mathrm{Cl}_{2}$ ) to give a brown solid $4 \quad(875 \mathrm{mg}, \quad 82 \%), \quad R_{f}=0.27 \quad(1: 19$ $\mathrm{MeOH} / \mathrm{CH}_{2} \mathrm{Cl}_{2}$ ), mp 135-137 ${ }^{\circ} \mathrm{C}$. ${ }^{1} \mathrm{H}$ NMR (DMSO$\left.\mathrm{d}_{6}\right): \delta 7.35(\mathrm{~s}, 2 \mathrm{H}, \mathrm{Ph}-\mathrm{H}), 7.66\left(\mathrm{~s}, 2 \mathrm{H}, \mathrm{NH}_{2}\right) . \mathrm{MS}$ (ESI): $214\left([\mathrm{M}+\mathrm{H}]^{+}, 100 \%\right)$; MS (ESI): $212\left([\mathrm{M}-\mathrm{H}]^{-}\right.$, $70 \%)$.

(f). General procedure for synthesis of compounds $\mathbf{5 a}$ $\boldsymbol{c}$ : Compound 4 (213 mg, $1.0 \mathrm{mmol}$ ) and 3-substituted benzoic acid $(1.0 \mathrm{mmol})$ were dissolved in $10 \mathrm{~mL}$ of dry $N, N$-dimethylformamide (DMF), HBTU $(417 \mathrm{mg}$, $1.1 \mathrm{mmol}$ ) and DIPEA (258 $\mathrm{mg}, 2.0 \mathrm{mmol}$ ) were added, and the reaction mixture was stirred at RT for $18 \mathrm{~h}$. Then the reaction mixture was concentrated in vacuo. The residue was washed with water, and dried in air to give crude product, which was purified by column chromatography on silica gel with eluent (1:99 to $5: 95 \mathrm{MeOH} / \mathrm{CH}_{2} \mathrm{Cl}_{2}$ ) to afford a white solid 5 .

Methyl 3-((2,2-difluoro-5H-

[1,3]dioxolo[4',5':4,5]benzo[1,2-d]imidazol-6-

yl) carbamoyl)benzoate (5a): Yield $63 \%, R_{f}=0.52$ (1:13 MeOH/ $\left./ \mathrm{CH}_{2} \mathrm{Cl}_{2}\right)$, mp 252-254 ${ }^{\circ} \mathrm{C}$. ${ }^{1} \mathrm{H}$ NMR (acetone- $\left.\mathrm{d}_{6}\right): \delta 3.90\left(\mathrm{~s}, 3 \mathrm{H}, \mathrm{OCH}_{3}\right), 7.35(\mathrm{~s}, 2 \mathrm{H}, \mathrm{Ph}-$ $\mathrm{H}), 7.71(\mathrm{t}, J=8.0 \mathrm{~Hz}, 1 \mathrm{H}, \mathrm{Ph}-\mathrm{H}), 8.23$ (dt, $J=1.5$, $8.0 \mathrm{~Hz}, 1 \mathrm{H}, \mathrm{Ph}-\mathrm{H}), 8.39$ (dt, $J=1.5,8.0 \mathrm{~Hz}, 1 \mathrm{H}, \mathrm{Ph}-$ $\mathrm{H}), 8.72(\mathrm{t}, J=1.5 \mathrm{~Hz}, 1 \mathrm{H}, \mathrm{Ph}-\mathrm{H}) . \mathrm{MS}(\mathrm{ESI}): 376$ $\left([\mathrm{M}+\mathrm{H}]^{+}, 25 \%\right) ; \mathrm{MS}(\mathrm{ESI}): 374\left([\mathrm{M}-\mathrm{H}]^{-}, 100 \%\right)$.

3-(Benzyloxy)- $\mathrm{N}-(2,2$-difluoro-5H-

[1,3]dioxolo[4',5':4,5]benzo[1,2-d] imidazol-6-

$y$ l)benzamide (5b): Yield 18\%, $R_{f}=0.67 \quad(1: 9$ $\mathrm{MeOH} / \mathrm{CH}_{2} \mathrm{Cl}_{2}$ ), mp 221-223 ${ }^{\circ} \mathrm{C} .{ }^{1} \mathrm{H}$ NMR (acetone$\left.\mathrm{d}_{6}\right): \delta 7.30-7.32(\mathrm{~m}, 3 \mathrm{H}, \mathrm{Ph}-\mathrm{H}), 7.33(\mathrm{dt}, J=2.0,7.0$ $\mathrm{Hz}, 1 \mathrm{H}, \mathrm{Ph}-\mathrm{H}), 7.39$ (tt, $J=1.5,8.5 \mathrm{~Hz}, 2 \mathrm{H}, \mathrm{Ph}-\mathrm{H}$ ),
7.45-7.51 (m, 3H, Ph-H), 7.76 (td, $J=1.0,8.0 \mathrm{~Hz}, 1 \mathrm{H}$, $\mathrm{Ph}-\mathrm{H}$ ), 7.80 (t, $J=2.0 \mathrm{~Hz}, 1 \mathrm{H}, \mathrm{Ph}-\mathrm{H}), 11.80$ (br s, $1 \mathrm{H}$, NH). MS (ESI): $424\left([\mathrm{M}+\mathrm{H}]^{+}, 9 \%\right)$; MS (ESI): 422 ([M-H], $100 \%)$.

$N$-(2,2-Difluoro-5H-[1,3]dioxolo[4',5':4,5]benzo[1,2d]imidazol-6-yl)-3-methoxybenzamide (5c): Yield $21 \%, R_{f}=0.54\left(1: 13 \mathrm{MeOH} / \mathrm{CH}_{2} \mathrm{Cl}_{2}\right)$, mp 241-243 ${ }^{\circ} \mathrm{C}$. ${ }^{1} \mathrm{H}$ NMR (DMSO-d $\left.\mathrm{d}_{6}\right): \delta 3.87\left(\mathrm{~s}, 3 \mathrm{H}, \mathrm{OCH}_{3}\right), 7.21$ (ddd, $J=1.0,2.5,8.0 \mathrm{~Hz}, 1 \mathrm{H}, \mathrm{Ph}-\mathrm{H}$ ), $7.31-7.33$ (br s, 2H, Ph-H), 7.47 (t, $J=8.0 \mathrm{~Hz}, 1 \mathrm{H}, \mathrm{Ph}-\mathrm{H}), 7.70$ (t, $J=$ $7.0 \mathrm{~Hz}, 1 \mathrm{H}, \mathrm{Ph}-\mathrm{H}), 7.73$ (dd, $J=1.0,1.5 \mathrm{~Hz}, 1 \mathrm{H}, \mathrm{Ph}-$ H), 7.75 (td, $J=1.0,1.5 \mathrm{~Hz}, 1 \mathrm{H}, \mathrm{Ph}-\mathrm{H}), 11.80$ (br s, $1 \mathrm{H}, \mathrm{NH})$. MS (ESI): $348\left([\mathrm{M}+\mathrm{H}]^{+}, 25 \%\right)$; MS (ESI): $\left.346([\mathrm{M}-\mathrm{H}]]^{-}, 100 \%\right)$.

$(g)$.

3-((2,2-Difluoro-5H-

[1,3]dioxolo[4',5':4,5]benzo[1,2-d]imidazol-6-

yl)carbamoyl)benzoic acid (6a): Potassium hydroxide $(\mathrm{KOH}, 0.5 \mathrm{~g}, 7.6 \mathrm{mmol})$ was added into the solution of compound 5a $(375 \mathrm{mg}, 1.0 \mathrm{mmol})$ in methanol $(20$ $\mathrm{mL}$ ). The reaction mixture was stirred at RT for $15 \mathrm{~h}$. Then the reaction mixture was concentrated in vacuo, and $\mathrm{HCl}(1 \mathrm{~N})$ was added to adjust $\mathrm{pH}$ to 7 . The resulting precipitate was filtered, washed with cold water, dried in air to give a white solid $6 \mathbf{6}(336 \mathrm{mg}$, $93 \%), R_{f}=0.20\left(1: 9 \mathrm{MeOH} / \mathrm{CH}_{2} \mathrm{Cl}_{2}\right), \mathrm{mp}>310^{\circ} \mathrm{C} .{ }^{1} \mathrm{H}$ NMR (DMSO-d $\mathrm{d}_{6}$ ): $\delta 7.48$ (s, 2H, Ph-H), $7.63(\mathrm{t}, J=$ $7.5 \mathrm{~Hz}, 1 \mathrm{H}, \mathrm{Ph}-\mathrm{H}), 8.16$ (d, $J=7.5 \mathrm{~Hz}, 1 \mathrm{H}, \mathrm{Ph}-\mathrm{H})$, 8.26 (d, $J=7.5 \mathrm{~Hz}, 1 \mathrm{H}, \mathrm{Ph}-\mathrm{H}), 12.55$ (br s, $1 \mathrm{H}, \mathrm{OH}$ ). MS (ESI): $362\left([\mathrm{M}+\mathrm{H}]^{+}, 15 \%\right)$; MS (ESI): 360 ([M$\mathrm{H}]^{-}, 25 \%$ ). HRMS (ESI): calcd for $\mathrm{C}_{16} \mathrm{H}_{10} \mathrm{~N}_{3} \mathrm{O}_{5} \mathrm{~F}_{2}$, $362.0589\left([\mathrm{M}+\mathrm{H}]^{+}\right)$, found 362.0579 .

(h).

$\mathrm{N}$-(2,2-Difluoro-5H-

[1,3]dioxolo[4',5':4,5]benzo[1,2-d]imidazol-6-yl)-3-

hydroxybenzamide $(\boldsymbol{\sigma} \boldsymbol{b}): \mathrm{BF}_{3} \mathrm{OEt}_{2}(0.8 \mathrm{~mL})$ and $\mathrm{Me}_{2} \mathrm{~S}$ $(1.0 \mathrm{~mL})$ were added to a solution of compound $\mathbf{5 b}$ $(212 \mathrm{mg}, 0.5 \mathrm{mmol})$ in dichloromethane $(20 \mathrm{~mL})$ at 0 ${ }^{\circ} \mathrm{C}$. The resulting mixture was stirred at $0{ }^{\circ} \mathrm{C}$ for $2 \mathrm{~h}$ and at RT for $2 \mathrm{~h}$. Then the reaction mixture was evaporated to dryness in vacuo. The residue was suspended in a mixture of aqueous $\mathrm{NaHCO}_{3}$, and extracted with EtOAc $(3 \times 80 \mathrm{~mL})$. The combined organic layers were washed with brine, dried over $\mathrm{Na}_{2} \mathrm{SO}_{4}$, and concentrated. The residue was purified by column chromatography on silica gel with eluent $\left(2: 98 \mathrm{MeOH} / \mathrm{CH}_{2} \mathrm{Cl}_{2}\right)$ to give a white solid $\mathbf{6 b}(109$ $\mathrm{mg}, 65 \%), R_{f}=0.50\left(7: 93 \mathrm{MeOH} / \mathrm{CH}_{2} \mathrm{Cl}_{2}\right)$, mp 249$251{ }^{\circ} \mathrm{C} .{ }^{1} \mathrm{H}$ NMR (acetone- $\mathrm{d}_{6}$ ): $\delta 7.12$ (ddd, $J=0.5$, 2.5, 8.5 Hz, 1H, Ph-H), 7.30 (br s, 2H, Ph-H), 7.38 (t, $J=7.0 \mathrm{~Hz}, 1 \mathrm{H}, \mathrm{Ph}-\mathrm{H}), 7.65$ (ddd, $J=0.5,2.5,8.5 \mathrm{~Hz}$, 1H, Ph-H), 11.77 (br s, 1H, OH). ${ }^{13} \mathrm{C}$ NMR (acetone$\left.\mathrm{d}_{6}\right): \delta 113.44,115.54,115.79,118.49,119.94,120.55$, $130.76,135.39,140.32,143.37,148.67,158.61$, 167.45. MS (ESI): $334\left([\mathrm{M}+\mathrm{H}]^{+}, 60 \%\right)$; MS (ESI): 332 ([M-H] $\left.{ }^{-}, 100 \%\right)$. HRMS (ESI): calcd for $\mathrm{C}_{15} \mathrm{H}_{10} \mathrm{~N}_{3} \mathrm{O}_{4} \mathrm{~F}_{2}, 334.0639\left([\mathrm{M}+\mathrm{H}]^{+}\right)$, found 334.0625.

(i) $\quad\left[{ }^{11}\right.$ C]methyl 3-((2,2-difluoro-5H[1,3]dioxolo[4',5':4,5]benzo[1,2-d]imidazol-6yl)carbamoyl)benzoate $\left(\left[{ }^{1} \mathrm{C}\right] \mathbf{5 a}\right)$ and $N$-(2,2-difluoro5H-[1,3]dioxolo[4',5':4,5]benzo[1,2-d]imidazol-6-yl)- 
3-[ $\left[{ }^{11}\right.$ C]methoxybenzamide $\left(\left[{ }^{11} \mathrm{C}\right] \mathbf{5 c}\right): \quad\left[{ }^{11} \mathrm{C}\right] \mathrm{CO}_{2}$ was produced by the ${ }^{14} \mathrm{~N}(\mathrm{p}, \alpha){ }^{11} \mathrm{C}$ nuclear reaction in the small volume $\left(9.5 \mathrm{~cm}^{3}\right)$ aluminum gas target provided with the Siemens RDS-111 Eclipse cyclotron. The target gas consisted of $1 \%$ oxygen in nitrogen purchased as a specialty gas from Praxair, Indianapolis, IN. Typical irradiations used for the development were $58 \mu \mathrm{A}$ beam current and $20 \mathrm{~min}$ on target. The production run produced approximately $37.0 \mathrm{GBq}$ of $\left[{ }^{11} \mathrm{C}_{C^{2} \mathrm{CO}_{2}}\right.$ at EOB. The precursor $\mathbf{6 a}$ or $\mathbf{6 b}$ (0.1-0.3 mg) was dissolved in $\mathrm{CH}_{3} \mathrm{CN}(300 \mu \mathrm{L})$. To this solution was added aqueous $\mathrm{NaOH}(2 \mathrm{~N}, 2 \mu \mathrm{L})$. The mixture was transferred to a small reaction vial. No-carrier-added (high molar activity) $\left[{ }^{11} \mathrm{C}^{\mathrm{C}} \mathrm{CH}_{3} \mathrm{OTf}\right.$ that was produced by the gas-phase production method ${ }^{26}$ within $12 \mathrm{~min}$ from $\left[{ }^{11} \mathrm{C}\right] \mathrm{CO}_{2}$ through $\left[{ }^{11} \mathrm{C}_{\mathrm{CH}_{4}}\right.$ and $\left[{ }^{11} \mathrm{C} \mathrm{CH}_{3} \mathrm{Br}\right.$ with AgOTf column was passed into the reaction vial at RT until radioactivity reached a maximum ( $2 \mathrm{~min}$ ), and then the reaction vial was isolated and heated at $80{ }^{\circ} \mathrm{C}$ for $3 \mathrm{~min}$. The contents of the reaction vial were diluted with aqueous $\mathrm{NaHCO}_{3}(0.1 \mathrm{M}, 1 \mathrm{~mL})$. The reaction vial was connected to a 3-mL HPLC injection loop. The labeled product mixture solution was injected onto the semi-preparative HPLC column for purification. The product $\left[{ }^{11} \mathrm{C}\right] \mathbf{5 a}$ or $\left[{ }^{11} \mathrm{C}\right] \mathbf{5} \mathbf{c}$ fraction was collected in a recovery vial containing $30 \mathrm{~mL}$ water. The diluted tracer solution was then passed through a C-18 Light Sep-Pak cartridge, and washed with water $(3 \times 10$ $\mathrm{mL})$. The cartridge was eluted with EtOH $(3 \times 0.4$ $\mathrm{mL}$ ) to release the labeled product, followed by saline $(10-11 \mathrm{~mL})$. The eluted product was then sterilefiltered through a Millex-FG $0.2 \mu \mathrm{m}$ membrane into a sterile vial. Total radioactivity was assayed and total volume (10-11 $\mathrm{mL})$ was noted for tracer dose dispensing. The overall synthesis time including HPLC-SPE purification and reformulation was $~ 40$ min from EOB. The decay corrected radiochemical yield was $40-45 \%$. Retention times in the analytical HPLC system were: $t_{R} \mathbf{6 a}=4.77 \mathrm{~min}, t_{R} \mathbf{5 a}=6.13$ $\min , t_{R}\left[{ }^{11} \mathrm{C}\right] 5 \mathbf{a}=6.21 \mathrm{~min}$; and $\mathrm{t}_{\mathrm{R}} \mathbf{6} \mathbf{b}=4.82 \mathrm{~min}, \mathrm{t}_{\mathrm{R}} \mathbf{5 c}$ $=6.34 \mathrm{~min}, \mathrm{t}_{\mathrm{R}}\left[{ }^{11} \mathrm{C}\right] \mathbf{5} \mathrm{c}=6.41 \mathrm{~min}$. Retention times in the preparative HPLC system were: $t_{R} \mathbf{6 a}=5.85 \mathrm{~min}$, $t_{R} \mathbf{5 a}=10.02 \mathrm{~min}, \mathrm{t}_{\mathrm{R}}\left[{ }^{11} \mathrm{C}\right] \mathbf{5 a}=10.18 \mathrm{~min}$; and $\mathrm{t}_{\mathrm{R}} \mathbf{6} \mathbf{b}=$ $6.05 \mathrm{~min}, \mathrm{t}_{\mathrm{R}} \mathbf{5} \mathbf{c}=10.23 \mathrm{~min}, \mathrm{t}_{\mathrm{R}}\left[{ }^{11} \mathrm{C}\right] \mathbf{5} \mathbf{c}=10.38 \mathrm{~min}$. 


\section{Synthesis of carbon-11-labeled CK1}

inhibitors as new potential PET

radiotracers for imaging of

\section{Alzheimer's disease}

Mingzhang Gao, Min Wang, Qi-Huang

$$
\text { Zheng* }
$$

Department of Radiology and Imaging

Sciences, Indiana University School of

Medicine, 1345 West $16^{\text {th }}$ Street, Room

202, Indianapolis, IN 46202, USA

- New carbon-11-labeled CK1 inhibitors were synthesized.

- A fully automated multi-purpose $\left[{ }^{11} \mathrm{C}\right]$ radiosynthesis module was built up.

- A semi-preparative RP HPLC-SPE technique was employed in radiosynthesis. 
Synthesis of carbon-11-labeled CK1 inhibitors as new potential PET radiotracers for imaging of Alzheimer's disease Mingzhang Gao, Min Wang, Qi-Huang Zheng*<smiles>C[18O]C(=O)c1cccc(C(=O)Nc2nc3cc4c(cc3[nH]2)OC(F)(F)O4)c1</smiles>

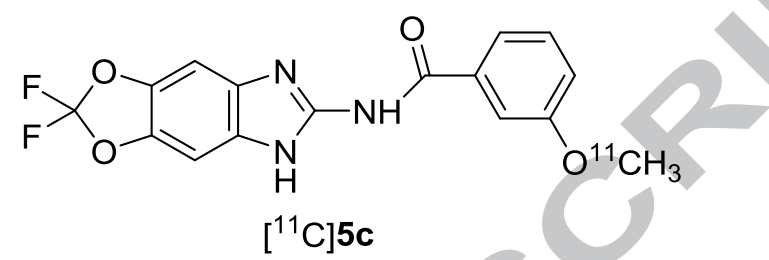

Carbon-11-labeled CK1 inhibitors 